\title{
Volumetric estimation of coal resources in seam VI for require backfill Materials of Barapukuria coal mine, Dinajpur, Bangladesh
}

\author{
Md. Mostafijul Karim, M. Farhad Howladar \\ Department of Petroleum \& Mining Engineering, Shahjalal University of Science \& Technology, Sylhet
}

Email address:

farhadpme@gmail.com (M. F. Howladar), mostafijpge@yahoo.com (M. Karim)

To cite this article:

Md. Mostafijul Karim, M. Farhad Howladar. Volumetric Estimation of Coal Resources in Seam VI for Require Backfill Materials of Barapukuria Coal Mine, Dinajpur, Bangladesh. Earth Science. Vol. 2, No. 6, 2013, pp. 113-119. doi: 10.11648/j.earth.20130206.11

\begin{abstract}
Through the distinguish software application along with formal calculation method the study represents a volumetric estimation of require backfill Materials of Barapukuria coal mine in north western Bangladesh, the only coal mine of the country under production, which capable of a low recovery with sustaining mining method. The only productive coal seam of the mine, Seam VI is our main focus during the assessment. Different estimation method is applied to investigate the accuracy of calculation and find out the reasons beyond the deflections. Surfer 8.4 exploits two method of interpolation, inverse distance to power, a weighted average interpolator and Kriging, more flexible gridding method, those yields the volume of 169221180.5 cubic meters and 165323770.4 cubic meters respectively. On the contrary Rockworks is estimated the volume through Delaunay Triangulation method as 115,959,398.4 cubic meters whether another estimation which is made by inverse power weighting interpolation on saved stratigraphic model, gives 174,281,203 cubic meters volume, following 185,760,000 cubic meters through geological reserve calculation. After considering the interpolation approach, available data and previous study agreement, the result of inverse distance to power, at both of software's is consider for backfill materials volume estimation. The required volume of backfill materials is $101532708.3 \mathrm{~m}^{3}$ and for $9 \%$ and $10 \%$ recovery that's are $9137943.747 \mathrm{~m}^{3}$ and $10153270.83 \mathrm{~m}^{3}$ respectively. The daily requirement of backfill is $562-636 \mathrm{~m}^{3}$ and the system need to have a daily capacity of $702-795 \mathrm{~m}^{3}$.
\end{abstract}

Keywords: Barapukuria Coal Mine, Backfill, Volume, Interpolation, Grid

\section{Introduction}

The Barapukuria coal mine is located at $50-\mathrm{km}$ east of the district capital Dinajpur, the northwest part of Bangladesh. According to Geological Survey of Bangladesh (GSB), who discovered the presence of coal reserve in April 1985, the reserve sustains with six layers, among of them $6^{\text {th }}$ seam is most significant as it contain about $90 \%$ of the total reserve and the reserve is identified at average depth of $118-509 \mathrm{~m}$. The mine has been extracting bituminous coal since 2005 with multi-slice longwall mining method when recovery percentage of this mine is very low.

Mine backfilling with a growing demand emerge in the mining area in recent times. It is considered as a most developing sector at mining aspect due to its significant role in increasing both the ore recovery and life of a mine by providing mine stability. Backfilling has not yet implemented in Barapukuria coal field. To assess the backfilling in Barapukuria for the first time we estimate require volume of backfill materials though the determination of volume of seam VI which is our main concern. Different software is implemented with different methods for estimation. The study is conducted by Surfer 8.4 (Surface mapping and computing software) (Golden Software, Golden, Colorado, USA) and Rockworks Version 14 (Rockwork Inc. Golden Co, USA). Different estimation method is applied to inspect the accuracy of calculation and then elaborate the reason of deflections. The calculation is based on the different borehole data. Fig. 1 shows the location of boreholes. The data used for volume estimation are 18 borehole logs among them 7 logs (GDHs) are surface drilled borehole and was drilled and recorded by Geological Survey of Bangladesh in 1985-1988 during their exploration process. The rest of the logs (DOBs) recorded by Wardell Armstrorg Mining Consultants in 1989-1990 at their feasibility study in the purpose of mining prospect [1]. 
Both the Software is using the gridding method. After extracting the spatial and thickness data from each borehole, grid files are automatically generated. Then the volume estimation is done for each cell by using different approach of interpolation and integration, in exception Rockwork read

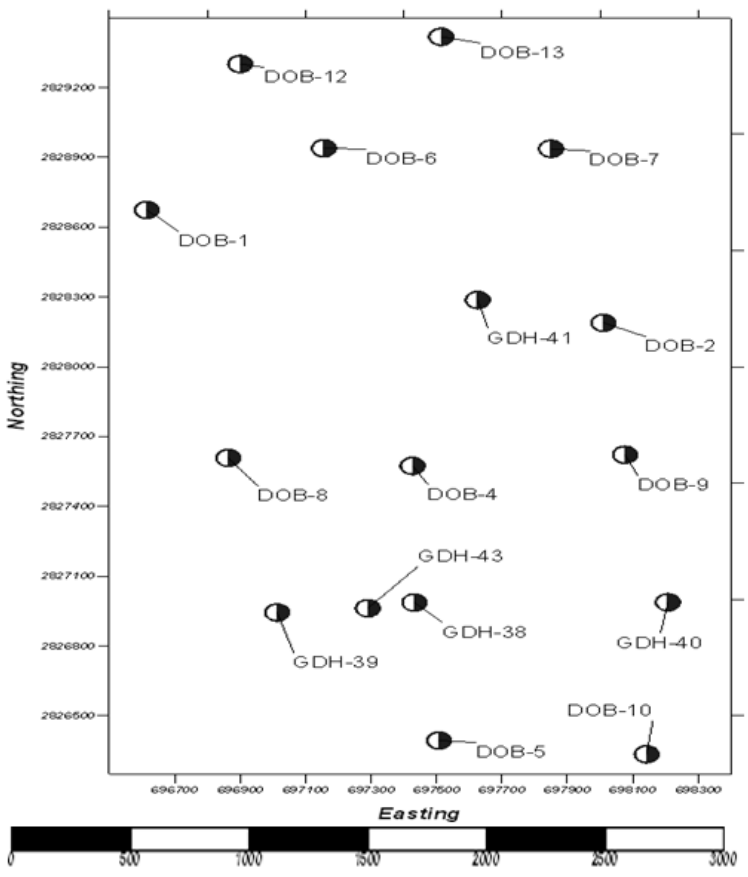

Fig 1: Location of 18 boreholes, those used in volume estimation (Surfer 9)

an existing stratigraphic solid model and computes volume of each rock or soil type whether Surfer uses classical numerical integration algorithms to ensure the accuracy. A formal calculation is made by Geological Reserve Calculation Method after Boki (1967) equation. Through a detailed discussion about every derived result, the estimated volume is determined after available data types, quantity and calculation methodology consideration.

\subsection{Geological Existence of Coal in Barapukuria Coals Mine}

The Barapukuria coal mine is located at the northwest part of Bangladesh, between longitude $88^{0} 56^{\prime} 36^{\prime \prime} \mathrm{E}-88^{0} 59^{\prime} 02^{\prime \prime} \mathrm{E}$, and latitude $25^{0} 34^{\prime} 40^{\prime /} \mathrm{N}-25^{0} 31^{\prime} 28^{\prime /} \mathrm{N}$ with an approximately $5 \mathrm{~km}^{2}$ basin area. The basin host the Permian aged coal belongs to Gondowana Group. Within the basin area the surface elevation is 30 to $32 \mathrm{~m}$ above mean sea level. The coalfield consists of six seams; those are marked as I to VI, of which the lower seam VI is being mined. The coal basin is categorized an asymmetrical faulted syncline with an approximately N-S axis. The coal bearing Gondowana formation rests on the Precambrian Basement complex. The structural sequence of the basin, with a varying thickness of maximum $390 \mathrm{~m}$, is divided into four formations named as Madhupur clay, DupiTila formation; separated as upper and lower DupiTila and only ground water containing formation, Gondwana Group and Pre-Cambrian Basement complex. dominant lithological components of the sequence are continental arenaceous sediments, with subordinate siltstones, shales. (Wardel Armstrong, 1991, Islam and Hayasi, 2008)[1, 11]

Figure 2 represents two dimensional Strip logs of four boreholes among the 18; those are used in volumetric calculation. Seam-I is only present in one borehole (GDH-40). Seam II and IV seem to be the most horizontally and their thickness differs between 2.5 to $15 \mathrm{~m}$. Seam III and $\mathrm{V}$ are laterally variable and discontinuous. Among the all seam VI is the thickest and laterally continuous in the basin whether its thickness varies from $22 \mathrm{~m}$ to $42 \mathrm{~m}$. Seam VI contains most of coal reserve of the mine. Sandstone exists as roof and floor of coal layer although a thin mudstone horizon is frequently present as the immediate roof. The coal
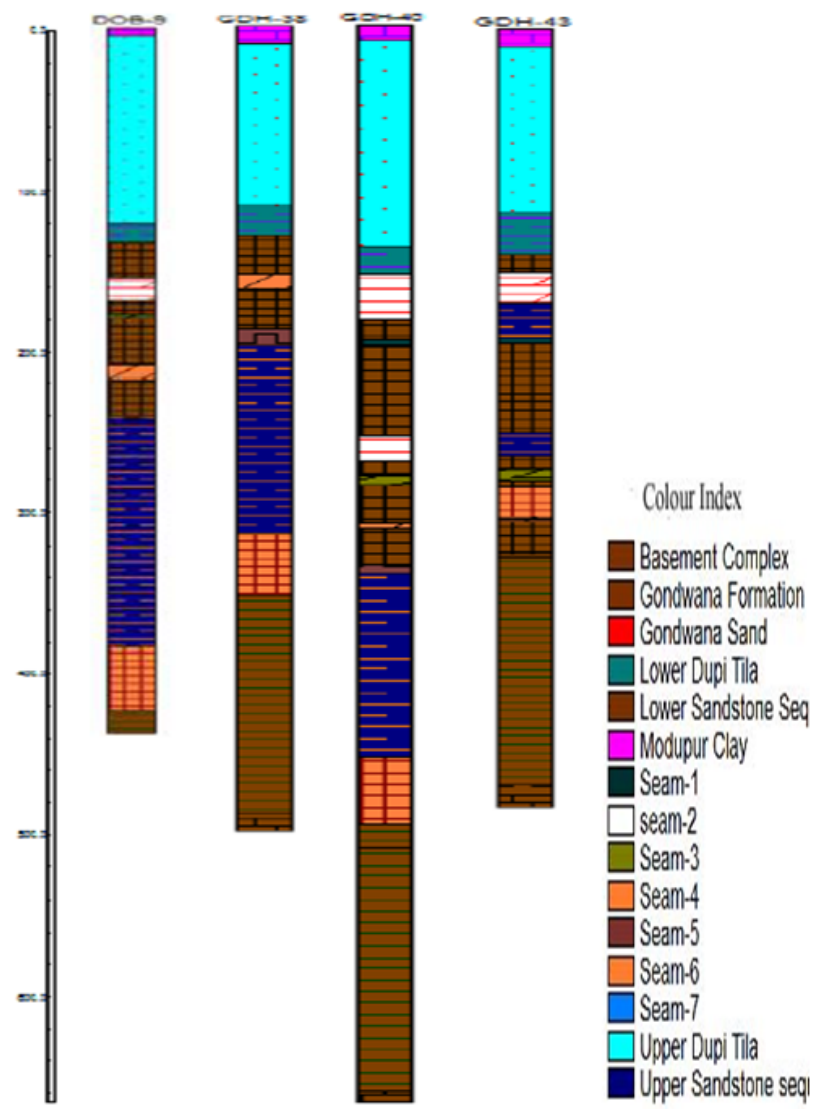

Fig 2: 2D Strip log of Different Borehole (By RockWorks/15).

Resources were formed in cold environments and deposited in association with lacustrine conditions (Wardell Armstrong, 1991; Bakr et al., 1996, Islam and Hayasi, 2008) $[1,2,11]$. Seam VI roof is consist of of $15 \mathrm{~m}$ to $140 \mathrm{~m}$ of relatively homogeneous and massive pale grey to white, medium to coarse-grained sandstones, gritstone, and conglomerates and strongly kaolinized, forming a white clay matrix which significantly lessens the primary permeability. The floor sandstone below the seam VI is different in composition from the above Gondwana sequence and dominantly consists of an interbedded sequence of sandstone, siltstone, and mudstone. Fluviatile sandstone and interbedded sandstone or siltstone sequences also repeatedly 
found with infrequent thin and discontinuous coal (Wardel Armstrong, 1991, Islam and Hayasi, 2008) [1, 11]. Figure 3 Illustrates a three dimensional model that represents the three-dimensional view of the strip logs of all enabled Boreholes.

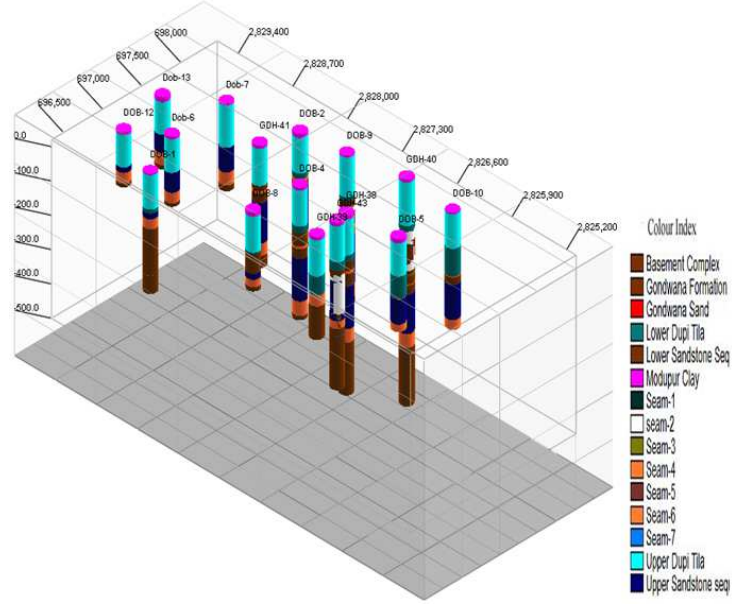

Fig 3: 3D Model that represents the three-dimensional view of the strip logs of all enabled Boreholes (By RockWorks/15)

\subsection{Role of Backfill in Coal Mine}

Backfill refers to any waste material that is placed into voids mined underground for the purposes of either disposal or to perform some engineering function. Backfilling of coal mines in the past has been primarily restricted to abandoned mines (Bloomfield, 1984) [3]. The purpose of the backfill is not to transmit the rock stresses, but to reduce the relaxation of the rock mass so the rock itself will retain a load carrying capacity and will improve load shedding to crown pillars and abutments (Barret et al., 1978) [4]. Research and in situ testing have shown that fill cannot rigidly support the total weight of overburden and acts only as a secondary support system (Cai, 1983) [5]. According to Brady and Brown (1985) backfill works as a support medium in three ways [6]. By imposing a kinematic constraint on the displacement of key pieces in a stope boundary, Secondly, both pseudo-continuous and rigid body displacements of stope wall rock, Finally, as a global support element in the mine structure. Materials used as mine backfill or components of a fill mass are of five types (J. Palarski 1994, Tony Grice 1998, Thomas et al 1979) [7, 8, 9] as run-of-mill concentrator tailings, used with a cementing agent to form paste fill, deslimed mill or concentrator tailings, or sandfill, natural sands, aggregates, development mullock and similar coarse, cohesionless media, cementing agents of various types. In the case of Barapukuria Coal mine the available backfill materials are Sand, Mine Tailing, Fly Ash and Cement. Volumetric estimation of the mineable area of the coalfield will reveal the require backfill materials volume and it will also play a rule in determination of the suitable backfill method which typically depends on available Backfill materials.

\section{Methods of the Study}

The calculation is based on the different borehole data. The data used for volume estimation of the seam six are 18 borehole logs among them 7 logs (GDHs) drilled and recorded by Geological Survey of Bangladesh in 1985 and the rest of the logs (DOBs) conducted by Wardell Armstrorg

Table 1: Upper and lower surface depth of seam VI with different borehole location. (Wardel Armstrong, 1991, Islam and Hayasi, 2008) [1,11]

\begin{tabular}{|c|c|c|c|c|c|}
\hline ID no & Easting & Northing & $\begin{array}{l}\text { Seam } \\
\text { Roof(m) }\end{array}$ & $\begin{array}{l}\text { Seam } \\
\text { Floor(m) }\end{array}$ & $\begin{array}{l}\text { Thickne } \\
\text { ss(m) }\end{array}$ \\
\hline DOB-1 & 696615 & 2828674 & 131.8 & 161.2 & 29.40 \\
\hline DOB-2 & 698010 & 2828189 & 291.4 & 328.4 & 37 \\
\hline DOB-4 & 697427 & 2827574 & 331.15 & 373.45 & 42.30 \\
\hline DOB-5 & 697508 & 2826394 & 249.1 & 271 & 21.3 \\
\hline DOB-6 & 697156 & 2828939 & 163.35 & 193.72 & 30.37 \\
\hline DOB-7 & 697850 & 2828937 & 199.55 & 237.6 & 38.05 \\
\hline DOB-8 & 696864 & 2827608 & 195.8 & 217.43 & 21.63 \\
\hline DOB-9 & 698076 & 2827622 & 381.62 & 421.37 & 39.75 \\
\hline DOB-10 & 698142 & 2826335 & 312.7 & 341.4 & 28.70 \\
\hline DOB-12 & 696900 & 2829301 & 118.65 & 149.49 & 30.84 \\
\hline DOB-13 & 697514 & 2829418 & 162 & 198 & 36 \\
\hline GDH-38 & 697432 & 2826987 & 331.62 & 371.24 & 39.62 \\
\hline GDH-39 & 697013 & 2826944 & 170.33 & 203 & 32.62 \\
\hline GDH-40 & 698207 & 2826988 & 450.19 & 491.03 & 40.84 \\
\hline GDH-41 & 697626 & 2828287 & 285.27 & 321.56 & 36.29 \\
\hline GDH-43 & 697290 & 2826962 & 286.82 & 329.19 & 42.37 \\
\hline
\end{tabular}

Mining Consultants in 1989-1990 [11]. The study is conducted by Surfer 8.4 (Surface mapping and computing software) (Golden Software, Golden, Colorado, USA), Rockworks Version 14 (Rockwork Inc. Golden Co, USA). Gridding method is common in both applications.

\subsection{Gridding Method}

In this process initially the borehole logs are converted to a common data format and spatial information are converted to planner earth projection UTM (Universal Transverse Marketer). Then volume calculations are performed on solids defined by an upper and lower surface. The upper and lower surfaces are defined by a grid file or a plane of 
constant $\mathrm{Z}$ level. Blanked regions on either the upper or the lower surface are excluded from consideration during the volume calculations.

Volume calculations are generated for each grid cell. In areas where the surface is tilted at the top or bottom of a grid cell, surfer approximates the volume of the prism at the top or bottom of the grid cell column. For very coarse grids, the prisms can contain a significant volume. Volume calculations become more accurate as the density of the grid is increased.

Mathematically, the volume under a function $f(x, y)$ is defined by a double integral(Stewart 1995) [10],

$$
\text { Volume }=\int_{X \min }^{X \max } \int_{Y \min }^{Y \max } f(x, y) d x d y
$$

In Surfer, this is computed by first integrating over X (the columns) to get the areas under the individual rows, and then integrating over Y (the rows) to get the final volume. We use two different methods for calculation, Inverse Distance to a Power and Kriging method. The yield volume is in cubic meter units. Then the volume is converted to acre-foot. Finally we get the tons of coal by multiplying the result by conversion factor (tons/acre-foot).

Rockwork uses the Borehole Manager's Stratigraphy -Volume tool to read an existing stratigraphic solid model and compute volume of each rock or soil type. The resulting computations are displayed in the Geological Utilities datasheet. This program assumes an already created solid model that illustrates the distribution of the desired material. This can be created using the Borehole Manager Model tools (Lithology, Stratigraphy). This program also assumes that already created grid model of the surface topography that will be used when modeling. The surface grid model must have the same dimensions and node counts as the $\mathrm{X}$ and $\mathrm{Y}$ dimensions of the input solid model.

"EZ Volume" reads a column of thickness values from the datasheet and computes volume using a Delaunay triangulation method. The output is a textual report.

\subsection{Geological Reserve Calculation Method}

The geological reserves were estimated by the following equation (Boki, 1967).

$\mathrm{Q}=\mathrm{S} \mathrm{m} \gamma$, tons

Where, $\mathrm{m}=$ Average thickness of coal seam (36 m).

$\gamma=$ Average specific gravity of bituminous coal $\left(1.32 \mathrm{t} / \mathrm{m}^{3}\right.$; GSB, 1992)

$\mathrm{S}=$ Area of the coal seam $\left(5.16 \mathrm{Km}^{2}\right)$

\section{Results and Discussions}

In Surfer volume calculations are performed on solids defined by an upper (Fig. 4) and lower surface (Fig. 5) and the data assigning from the Table 1.

Surfer approximates the necessary one-dimensional integrals using three classical numerical integration algorithms: Extended Trapezoidal Rule, Extended Simpson's Rule, and Extended Simpson's 3/8 Rule. The difference in the volume calculations by the three different methods measures the accuracy of the volume calculations. If the three volume calculations are reasonably close together, the true volume is close to these values. If the three values differ somewhat, a new denser grid file should be used before performing the volume calculations again. According to Table 2 we get three values are nearly same so the net volume reported as the average of the three values. We use two different methods. One of them is Inverse Distance to a Power, is a type of deterministic method for multivariate interpolation with a known scattered set of points. The assigned values to unknown points are calculated with a weighted average of the values available at the known points (Shepard, 1968) [12]. The average volume by this method is 169221180.5 cubic meters and the estimated reserve is $271.22 \mathrm{Mt}$ (Table 2).

Table 2: Estimated Volume of Require Backfill Materials of Seam VI by Surfer 8.4: [Here, 1 acre=4046.85642 $\mathrm{m} 3 \mathrm{and} 1 \mathrm{~m}=3.28083333 \mathrm{ft}$, Tons of coal= (acre-foot)*(1976.97 tons/acre-foot)]

\begin{tabular}{|c|c|c|c|c|c|c|c|}
\hline Estimation Method & & $\begin{array}{l}\text { Volume } \\
\text { (cubic meter) }\end{array}$ & $\begin{array}{l}\text { Average } \\
\text { Volume(m3) } \\
\end{array}$ & Tons of coal & $\begin{array}{l}\text { Require backfill } \\
(\mathrm{Mm3})\end{array}$ & $\begin{array}{l}\text { Require } \\
\text { volume(I }\end{array}$ & $\begin{array}{l}\text { backfill } \\
\text { n3) }\end{array}$ \\
\hline \multirow{5}{*}{$\begin{array}{l}\text { Inverse Distance to a } \\
\text { Power }\end{array}$} & & & \multirow{5}{*}{169221180.5} & \multirow{5}{*}{271219662.7} & \multirow{5}{*}{101532708} & With $9 \%$ & With $10 \%$ \\
\hline & Trapezoidal Rule & 169221736.096 & & & & \multirow{4}{*}{9.14} & \multirow{4}{*}{10.15} \\
\hline & & & & & & & \\
\hline & Simpson's Rule & 169220805.802 & & & & & \\
\hline & Simpson's $3 / 8$ Rule & 169220999.698 & & & & & \\
\hline \multirow{3}{*}{ Kriging } & Trapezoidal Rule & 165322544.290 & \multirow{3}{*}{165323770.4} & \multirow{3}{*}{264973079.1} & \multirow{3}{*}{99194262.24} & \multirow{3}{*}{8.93} & \multirow{3}{*}{9.92} \\
\hline & Simpson's Rule & 165324335.236 & & & & & \\
\hline & Simpson's3/8 Rule & 165324431.864 & & & & & \\
\hline
\end{tabular}




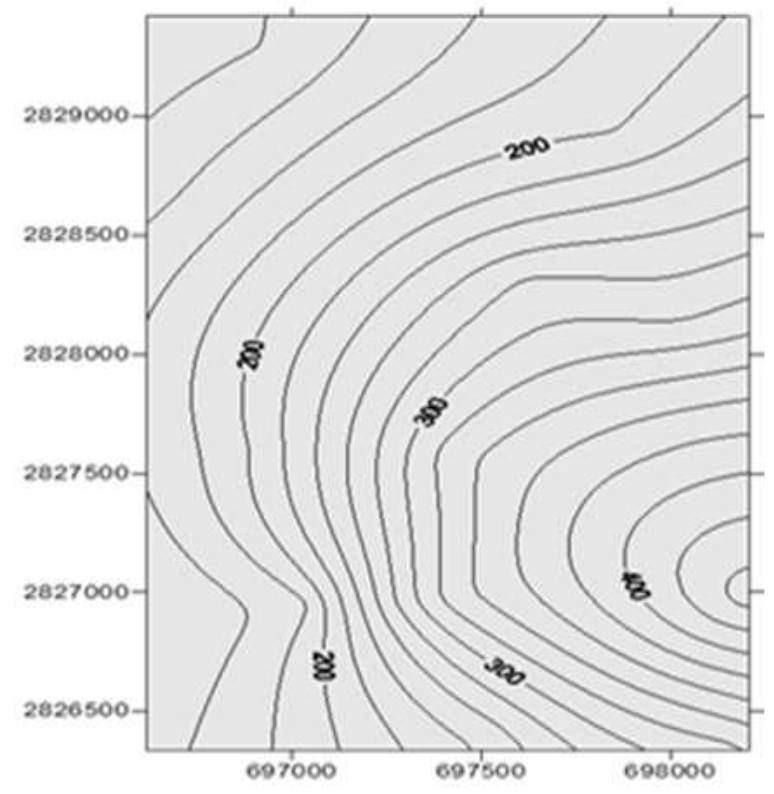

Fig 4: Contour Map of seam roof (Surfer 8.4).

The Inverse Distance to a Power gridding method is a weighted average interpolator, and can be either an exact or a smoothing interpolator. Normally, Inverse Distance to a Power behaves as an exact interpolator. On the other hand Kriging method is a geo-statistical estimator that assumes the value of a random field at an unobserved location from samples (Wahba, 1990) [13]. This method yields the volume of 165323770.4 cubic meters and the calculated coal reserve is $264.98 \mathrm{Mt}$ (Table 2).

Kriging is one of the more flexible methods and is useful for gridding almost any type of data set, and this geo-statistical gridding method that has proven useful and popular in many fields. This method produces visually appealing maps from irregularly spaced data. For this reason it produces more accurate result with a large number of data

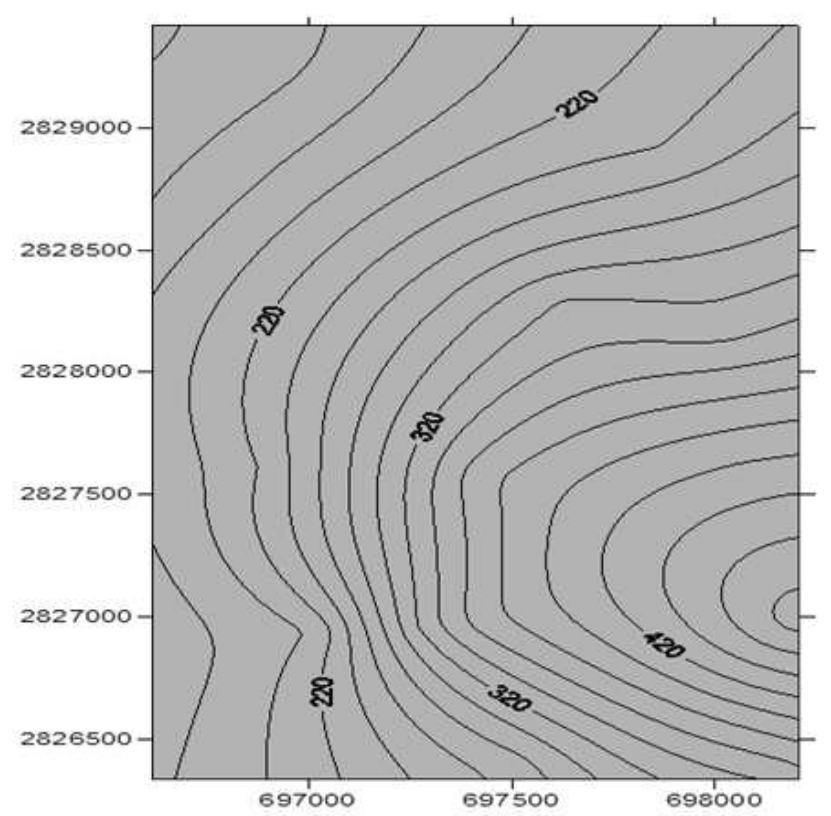

Fig 5: Contour Map of seam Floor (Surfer 8.4).

sets. Here for volume calculation we use only sixteen borehole data (Table 1). So the calculated volume is much lower than it actually has.

With Rockworks we also use two Methods. Initially Volumes are computed using a Delaunay triangulation method in which the samples are connected together in a network of triangles, a sample at each vertex. The volume of each triangle is computed, based on the thicknesses used as Z-values (Fig. 5), and then the total volume added up. This method tends to provide lower estimates of total volume than an orthogonal grid-based calculation. So the calculated volume with this method is lowest compare with others and it is $115,959,398.4$ cubic meters when the estimated reserve is $185.85 \mathrm{Mt}$ (Table 3$)$.

Table 3: Estimated Volume of Require Backfill Materials of Seam VI by Rockworks (Version 14):

\begin{tabular}{|c|c|c|c|c|c|}
\hline Estimation Method & Volume (cubic meter) & Tons of coal & Require backfill $\left(\mathrm{Mm}^{3}\right)$ & $\begin{array}{l}\text { Require } \\
\text { volume(N }\end{array}$ & backfill \\
\hline & & & & With 9\% & With $10 \%$ \\
\hline Delaunay Triangulation (EZ value) & $115,959,398.4$ & 185854210.5 & 69575639.04 & 6.26 & 6.96 \\
\hline $\begin{array}{l}\text { Stratigraphic volumes (Based on solid } \\
\text { Model) }\end{array}$ & $174,281,203$ & $279329626.2^{\prime}$ & 104568721.8 & 9.41 & 10.46 \\
\hline
\end{tabular}

At the second method Borehole Manager's StratigraphyVolume tool reads the saved stratigraphic model (Fig: 6) and compute volume of each layer. The resulting computations are displayed in the Geological Utilities datasheet. The volume of seam VI with this model is $174,281,203$ cubic meters and the calculated coal reserve is $279.33 \mathrm{Mt}$ (Table 3 ). The model resolutions is 100 that means the number of nodes along the $\mathrm{X}$ and $\mathrm{Y}$ axes of the grid models is 100, same as along the $\mathrm{Z}$ axis for the solid stratigraphic model. The using gridding method is inverse power weighting where the value 
assigned to a grid node is a weighted average of either all of the data points or a number of directionally distributed neighbors. So the Inverse-Distance method will not exaggerate its extrapolations beyond the given data points. The range of grid values will be smaller than the data point range: The highest grid value will be less than the maximum data point, and the lowest grid value will be greater than the minimum data point. So it produces a smooth and continuous grid and yields more reliable estimation results.

Furthermore after the Boki, 1997 equation the volume estimates as $185,760,000$ cubic meters, correspond the coal reserve of $245.2 \mathrm{Mt}$, when the average thickness is $36 \mathrm{~m}$ (as in Table 1), and area is $5.16 \mathrm{Km}^{2}$. The reserve calculated for coal seam VI during the mine feasibility study estimated as $271 \mathrm{Mt}$ by Warderl Armstrong Company. After conversion which gives $169084144.1 \mathrm{~m}^{3}$ volume. The calculation method is unknown. In another calculation the reserve is approximately $300 \mathrm{Mt}$, resemble to a volume of 187178000 $\mathrm{m}^{3}$, where calculation used polygon method (Islam and Hayashi, 2009) [11]. As we mention earlier with Inverse Distance to a Power, data are weighted during interpolation such that the influence of one point relative to another declines with distance from the grid node and will not exaggerate its extrapolations beyond the given data points, but the polygon method deals with regular

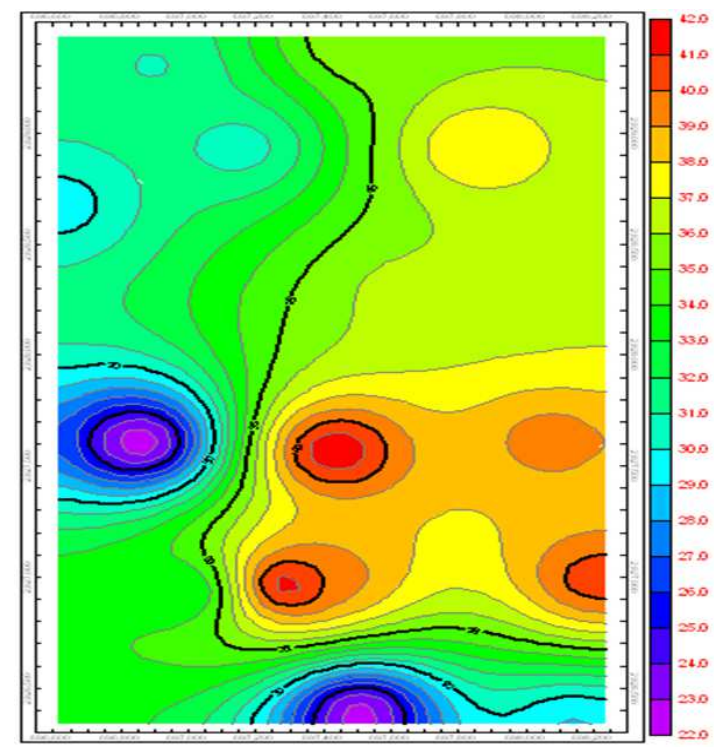

Fig 5: Seam VI thickness in 2-D (Rockwork).

variation of the phenomenon where assumed the point is well surrounded by experimental data and assigning the nearest measure value (Hunter, 2008) [14].

So, it is conspicuous that the calculation by inverse distance to power method in both can be considered as more accurate than others. Moreover it shows good agreements with Warderl Armstrong Company's calculation. According to inverse power weighting method used in surfer results denote that full extraction of seam VI will create $169221180.5 \mathrm{~m}^{3}$ void space when with recent recovery percentage creates $15229906.25 \mathrm{~m}^{3}$ to $16922118.05 \mathrm{~m}^{3}$ void spaces eventually. This is the important finding to select the backfill materials for the field because the available backfill resources have to have the require volumes. The typical requirement for backfill is approximately $50 \%$ of the tonnage mined. It is theoretically about $60 \%$, but all stopes are not completely filled and tertiary stopes may not be filled at all (Ross Gowan). As this rule of thumb the required volume of backfill materials is $101532708.3 \mathrm{~m}^{3}$ and with recovery rate that's $9 \%$ and $10 \%$ recovery the requirement are $9137943.747 \mathrm{~m}^{3}$ and $10153270.83 \mathrm{~m}^{3}$ respectively. The daily production of the mine is about $1500-1700$ tons of coal per day. If a mine backfills all production stopes to avoid significant delays in ore production, the daily capacity of the backfill system should be should be at least 1.25 times the average daily mining rate which expressed in terms of volume (Robert Currie). So the daily requirement of backfill is $562-636 \mathrm{~m}^{3}$ and the system need to have a daily capacity of $702-795 \mathrm{~m}^{3}$.

\section{Conclusions}

Bangladesh has just planned for coal based power plant to meet its energy crisis when the country cannot utilize its only producing coal mine efficiently, moreover local people

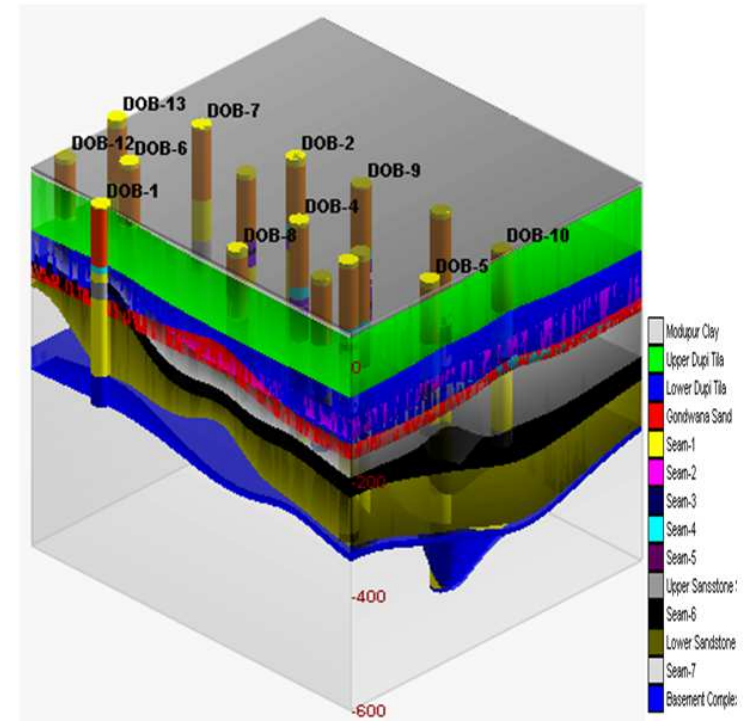

Fig 6: Stratigraphic solid model append with log Colum used in Rockwork during volume Estimation of Seam VI.

raise their voice against the mine activity as the mine induced subsidence is devastating the neighboring residential area. We conducting this study in the aim of the determination of the require volume of backfill along the the estimation of the reserve of the seam VI. That reveals the full extraction of seam VI will create $169221180.5 \mathrm{~m}^{3}$ void space when with recent recovery percentage creates 15229906.25 $\mathrm{m}^{3}$ to $16922118.05 \mathrm{~m}^{3}$ void spaces and required volume of backfill materials is $101532708.3 \mathrm{~m}^{3}$ and for $9 \%$ and $10 \%$ recovery are $9137943.747 \mathrm{~m}^{3}$ and $10153270.83 \mathrm{~m}^{3}$ respectively. The daily requirement of backfill is $562-636$ $\mathrm{m}^{3}$ and the system need to have a daily capacity of $702-795$ 
$\mathrm{m}^{3}$. Considering these requirement as well as the obtainable materials, sand dominated backfill, either in cemented or uncemented form, in hydraulic placement method can be recommended for Barapukuria coal mine. We also recommend a further study that will characterize the backfill materials and make an assessment of Backfilling of the mine.

\section{Acknowledgement}

Special thanks to the ministry of Science and Technology for their financial support during the research work. A cordial gratefulness to my parents for everything they have done to get me to this point. Without their constant love, dedication, and encouragement none of this would be possible.

\section{References}

[1] Wardell Armstrong 1991; Techno - economic Feasibility study of Barapukuria Coal Project, Dinajpur, Bangladesh.

[2] Bakr, M. A., Rahman, Q.M.A., Islam, M.K., Resan, S.A. Haider, M.j., Islam, M.S., Ali, M.W. Chowdhuary, E.A., Mannan, K.M., Anam, A.N.H.M., 1996. Geology and Coal deposits of Barapukuria Basin, Dinajpur District, Records of Geological Servey of Bangladesh, Vol. 8, Pt. 1

[3] Bloomfield, R.A., (1984), "Current Research Into the Potential for Utilization of Mine Waste," Journal of Testing and Evaluation, Vol. 12. No. 2, March, 119-122

[4] Barret, J.R., Coulthard, M.A., and Dight, P.M., (1978), "Determination of Fill Stability," Mining with Backfill - 12th Canadian Rock Mechanics Symposium, Canadian Institute of Mining and Metallurgy, Quebec, Special Vol. 19, 85-91.
[5] Cai, S. (1983), "A Simple and Convenient Method for Design of Strength of Cemented Hydraulic Fill," Proceedings of International Symposium on Mining with Backfill, A.A Balkema, Rotterdam, 405-412.

[6] B.H.G Brady \& E.T.Brown- Rock Mechanics for Un derground Mining, George Allen \& Unwin Publication, page 351-358 (1985 addition)

[7] J. Palarski - Design of backfill as support in Polish Coal mines, The journal of The south African Institute of mining and Metallurgy August 1994, page-218-225

[8] Tony Grice-Underground mining with backfill, The 2nd Annual Summit - Mine Tailings Disposal Systems, Brisbane, 24-25 November 1998 .

[9] Thomas, E.G., (1979), Fill Technology in Underground Metalliferous Mines International Academic Services Ltd., Kingston, Ontario, 293.

[10] James Stewart, Calculus (Early Trancendentals) 3rd Ed., Brooks/Cole, Pacific Grove, CA, 1995

[11] Md. Rafiqul Islam \&Daigoro Hayashi - Geology and coal bed methane resources potential of the Gondwana Barapukuria coal basin, dinajpur, Bangladesh. ElsevierInternational Journal of Coal Geology 75 (2008) Page $131-137$

[12] Shepard, Donald (1968). "A two-dimensional interpolation function for irregularly-spaced data". Proceedings of the 1968 ACM National Conference. pp. 517-524.

[13] Grace Wahba (1990). Spline Models for Observational Data 59. SIAM. p. 162.

[14] Don Hunter, PLS, California Department of Transportation, Areas and Volumes, unit-8, page 1-14 